\title{
Quality of breast meat from broiler chickens raised in Brazil affected by white striping myopathy
}

\author{
Qualidade da carne de peito de frangos de corte criados no Brasil contendo estrias brancas \\ Calidad de la carne de pechuga de pollos de engorde criados en Brasil, afectados por la miopatía de \\ estrías blancas
}

Juliana Lolli Malagoli de Mello ORCID: https://orcid.org/0000-0003-4648-1412 Universidade Estadual de São Paulo, Brasil E-mail: julianalolli@gmail.com

Rodrigo Alves de Souza ORCID: https://orcid.org/0000-0001-6129-9243 Universidade de São Paulo, Brasil

E-mail: rodrigo.zootecnista@gmail.com Fábio Borba Ferrari ORCID: https://orcid.org/0000-0002-9339-0911

Universidade Estadual de São Paulo, Brasil E-mail: fbf_zoo@ hotmail.com

Erika Nayara Freire Cavalcanti ORCID: https://orcid.org/0000-0003-2278-4929

Universidade Estadual de São Paulo, Brasil E-mail: erikanayarac@gmail.com

Rodrigo Fortunato de Oliveira ORCID: https://orcid.org/0000-0001-9608-5827

Universidade Estadual de São Paulo, Brasil E-mail: fortunatorodrigo@ymail.com

Heloisa de Almeida Fidelis

ORCID: https://orcid.org/0000-0002-5140-0835

Universidade Estadual de São Paulo, Brasil E-mail: heloisa.a.fidelis@gmail.com

Mateus Roberto Pereira

ORCID: https://orcid.org/0000-0002-9036-3758

Universidade Estadual de São Paulo, Brasil mateusscj2012@hotmail.com

Erick Alonso Villegas-Cayllahua ORCID: https://orcid.org/0000-0003-0939-9305

Universidade Estadual de São Paulo, Brasil E-mail: evillegasc22@gmail.com

Aline Giampietro-Ganeco ORCID: https://orcid.org/0000-0002-6966-1902

Universidade de São Paulo, Brasil E-mail: algiamp@yahoo.com.br

Daniel Rodrigues Dutra ORCID: https://orcid.org/0000-0001-5435-243X

Universidade Estadual de São Paulo, Brasil E-mail: danielrdutra@hotmail.com Pedro Alves de Souza ORCID: https://orcid.org/0000-0002-2657-2045

Universidade Estadual de São Paulo, Brasil E-mail: p.souza@unesp.br

Hirasilva Borba

ORCID: https://orcid.org/0000-0001-7057-3945

Universidade Estadual de São Paulo, Brasil E-mail: hirasilva.borba@unesp.br

\begin{abstract}
The aim of this study was to characterize the breast meat from broilers affected by the white striping myopathy and examine its influence on meat quality. 180 breast samples from male broilers, slaughtered at 42-d-old, were used. Samples were classified according to the severity degree of apparent white stripes on the Pectoralis major muscle surface
\end{abstract}


("normal" [n=60], "moderate" [n=60], or "severe" $[n=60])$. Birds affected by the myopathy produced breast meat with higher L*, a* and b* values on the outer surface. Cooking loss decreased as the severity degree increased $(30.94 \%$ [normal] to $21.65 \%$ [severe]). Toughness increased in the samples classified as moderately and severely affected. There was also an increase in the concentrations of lipids (1.60\% [normal] to $2.57 \%$ [affected samples], on average), cholesterol $(84.60 \mathrm{mg} / 100 \mathrm{~g}$ [normal] to $91.73 \mathrm{mg} / 100 \mathrm{~g}$ [severe degree]) and collagen as the severity degree increased. Although there are statistical differences for some evaluated parameters and, even so, these results are considered numerically normal based on previously published literature, we emphasize that the white striping abnormality alters chicken breast meat quality, especially regarding to the protein and fat concentrations, which can offer consumers products with nutritional quality different from the average specified on the packaging.

Keywords: Chemical composition; Muscle abnormalities; Pectoralis major; Softness.

\section{Resumo}

O objetivo deste estudo foi caracterizar a carne de peito de frangos de corte acometidos por estrias brancas e examinar sua influência na qualidade da carne. Foram utilizadas 180 amostras de peito de frangos de corte machos, abatidos aos 42 dias de idade. As amostras foram classificadas de acordo com o grau de severidade das estrias brancas aparentes na superfície do músculo peitoral maior ("normal" $[\mathrm{n}=60]$, "moderado" $[\mathrm{n}=60]$ ou "severo" $[\mathrm{n}=60]$ ). As aves afetadas pela miopatia produziram carne de peito com maiores valores $\mathrm{L}^{*}, \mathrm{a}^{*} \mathrm{e} \mathrm{b}^{*}$ quando avaliada a superfície externa. As perdas por cozimento diminuíram conforme o grau de severidade da miopatia aumentou (30,94\% [normal] para 21,65\% [severo]). A dureza foi maior em amostras afetadas pelos graus moderado e severo. Também houve aumento nas concentrações de lipídios (1,60\% [normal] para 2,57\% [amostras afetadas], em média), colesterol (84,60 mg / $100 \mathrm{~g}$ [normal] para $91,73 \mathrm{mg} / 100 \mathrm{~g}$ [grau severo]) e colágeno conforme o grau de severidade aumentou. Embora existam diferenças estatísticas para alguns parâmetros avaliados e, mesmo assim, esses resultados sejam considerados numericamente normais com base na literatura publicada anteriormente, ressaltamos que a presença de estrias brancas altera a qualidade da carne de peito de frango, principalmente no que se refere às concentrações de proteínas e gorduras, o que pode oferecer ao consumidor produtos com qualidade nutricional diferente da média especificada nas embalagens. Palavras-chave: Anormalidades musculares; Composição química; Maciez; Pectoralis major.

\section{Resumen}

El objetivo de este estudio fue caracterizar la carne de pechuga de pollos de engorde afectados por las estrías blancas y evaluar su influencia en la calidad de la carne. Se utilizaron 180 muestras de pechuga de pollos, machos, sacrificados a los 42 días de edad. Las muestras se clasificaron según el grado de severidad de las estrías blancas presentes en la superficie del músculo pectoral mayor ("normal" [n=60], "moderado" [n=60] o "grave" [n=60]). Las aves afectadas por la miopatía produjeron una carne de pechuga con mayores valores de $\mathrm{L}^{*}, \mathrm{a}^{*} \mathrm{y} \mathrm{b}^{*}$ cuando se evaluó la superficie externa. Las pérdidas por cocción disminuyeron a medida que aumentaba el grado de severidad de la miopatía (30,94\% [normal] a $21,65 \%$ [grave]). La dureza fue mayor en las muestras afectadas por los grados moderado y severo. También hubo un aumento en las concentraciones de lípidos (1,60\% [normal] a 2,57\% [muestras afectadas por la miopatia], en promedio), colesterol (84,60 mg/100 g [normal] a $91,73 \mathrm{mg} / 100 \mathrm{~g}$ [grave]) y colágeno a medida que aumentaba el grado de severidad. Si bien existen diferencias estadísticas para algunos parámetros evaluados y, aun así, estos resultados se consideran numéricamente normales en base a la literatura publicada anteriormente, destacamos que la presencia de las estrías blancas altera la calidad de la carne de pechuga de pollo, especialmente en lo que respecta a las concentraciones de proteínas y grasas, que pueden ofrecer a los consumidores productos con una calidad nutricional diferente al promedio especificado en el empaque.

Palabras clave: Anomalías musculares; Composición química; Pectoralis major; Terneza.

\section{Introduction}

At present, the Brazilian poultry farming sector ranks third in worldwide chicken meat production, having produced 13.25 million tons of meat in 2019. In that year, Brazil was also the world's largest exporter of the product (4.2 million tons) and domestic consumption reached $43 \mathrm{~kg}$ per capita (ABPA, 2020). There is a trend for chicken meat to surpass red meat consumption, which is possibly linked to the lower prices of the former product. Thus, chicken meat is becoming more economically accessible to the low-income consumer, a phenomenon also helped by the commercial appeal to the white meat consumption, as a healthy alternative to red meat.

The evolution of poultry meat production has allowed for great product diversification, furthering the development of convenient, practical items with added value in lieu of the sale of whole carcasses. Due to the greater demand for chick-en meat, the market must constantly adapt to achieve better productivity indices. In this context, breeding emerged as the main tool to attain this goal, whereby high growth-performance lines are selected (Kuttappan et al. 2013). However, muscle lesions called 
myopathies have been observed in fast-developing chicken lines, and these are only detected at the time of slaughter.

These obstacles to the industry, such as the appearance of white stripes at different degrees of severity, have heightened the need for research on the physical, chemical and sensory changes genetic progress can introduce into the quality of the produced meat. Any condition that may negatively affect the visual appearance of meat results in economic losses (Kuttappan et al. 2012b). The visual change caused by myopathies on the appearance of chicken breast meat may render fresh meat and its derivatives unsuitable for marketing, since slaughterhouses adopt a policy of condemning carcasses with lesions of unknown etiology.

Lesions such as the white striping myopathy act as potential disadvantages to consumer acceptance and their intention to buy poultry meat (Kuttappan et al. 2012b). White striping is characterized by pale breast meat (Kuttappan et al. 2012a) with white stripes, often accompanied by signs of hemorrhage, which possibly results in consumer rejection at the time of purchase and, consequently, economic losses. Though its cause is not yet certain, the myopathy has affected the Brazilian poultry sector with its negative impact on the production of commercial birds. Considering this scenario and other studies under development, which are aimed at evaluating the characteristics of cuts affected with the above-mentioned myopathy, we conducted the present study to characterize the breast meat of broiler chickens raised under Brazilian conditions, affected with different degrees of white striping at and to examine its impact on meat quality.

\section{Methodology}

This study was developed at the Laboratory of Analysis of Animal Products at the Faculty of Agricultural and Veterinary

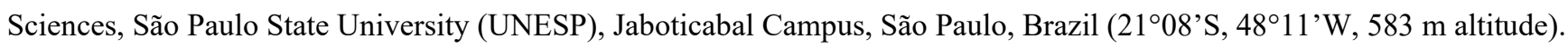

The study involved 180 breast samples collected from male Ross ${ }^{\circledR} 308$ (AP95) broiler chickens. The birds were slaughtered at 42 days of age in accordance with the protocol adopted by the slaughterhouse (inspected by the Federal Inspection Service). The samples were classified according to the degree of severity of apparent white stripes on the Pectoralis major muscle (white striping myopathy) into "normal" ( $\mathrm{n}=60)$ - absence of myopathy (control group); "moder-ate" ( $\mathrm{n}=60)$ - with white stripes up to 1-mm thick; or "severe" $(\mathrm{n}=60)$ - with white stripes thicker than $1 \mathrm{~mm}$, easily identified on the muscle surface, following the classification criterion described by Kuttappan et al. (2012a). The classification was performed by trained people and, posteriorly, were collected directly from the slaughter line. Samples were transferred to the laboratory in a refrigerated vehicle to maintain the cold chain and, after the establishment of rigor mortis ( $4 \mathrm{~h}$ post-slaughter), the samples underwent a physical analysis (color, pH, water-holding capacity, cooking loss and shear force). For the subsequent chemical analyses (chemical composition, collagen and cholesterol concentrations and sarcomere length), subsamples were vacuum-packed in plastic bags $(18 \mu)$ using a sealing ma-chine (200-B, Selovac, São Paulo, SP, Brazil) and frozen in a freezer $\left(-18^{\circ} \mathrm{C}\right)$ for a period no longer than 30 days until all analyzes were performed. The sampling diagram of physical-chemical analyses are shown in Figure 1. 
Figure 1. Sampling diagram of physical-chemical analyses in chicken breast meat.

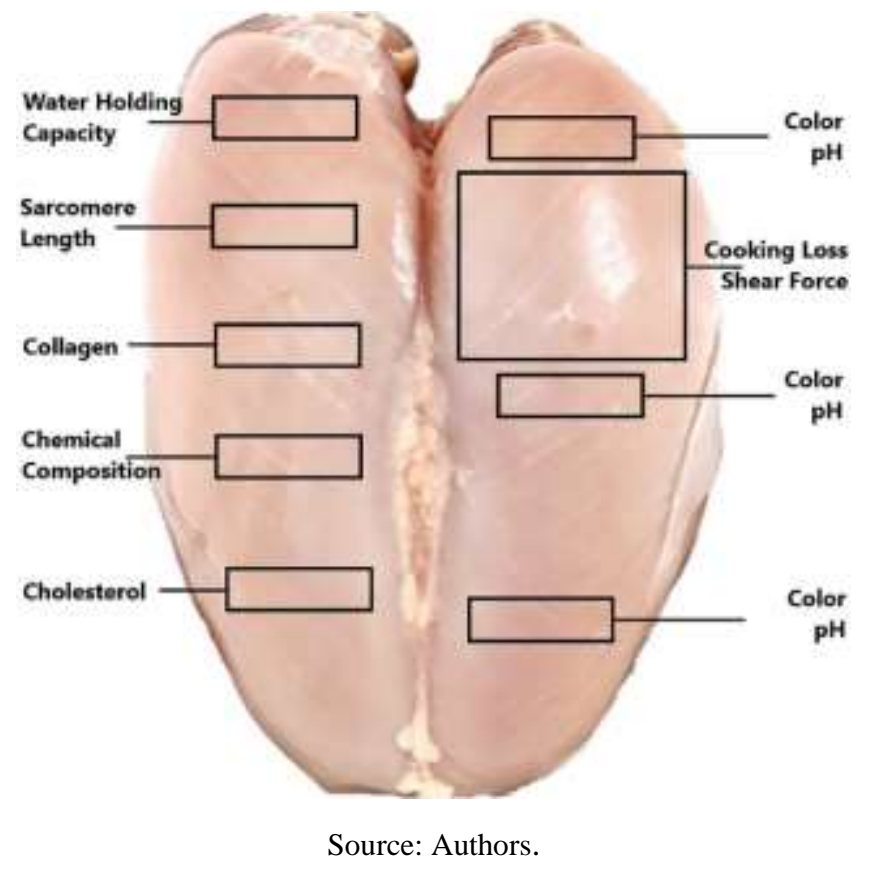

Color ( $\mathrm{L}^{*}$ - lightness; $\mathrm{a}^{*}$ - redness; $\mathrm{b}^{*}$ - yellowness) was determined using a colorimeter (CR-400, Konica Minolta Sensing Inc., Osaka, Japan) (settings: diffuse illumination $/ 0^{\circ}$ viewing angle, illuminant D65, specular component included) in three different portions of the outer surface of the Pectoralis major muscle (which was in contact with the skin - a region commonly affected with white striping) and also in the inner muscle surface, which was in contact with the sternum bone, immediately after deboning. The $\mathrm{pH}$ was determined in triplicate, using a digital pH meter (Testo 205, Testo Inc., Sparta, NJ, USA) equipped with a penetration electrode for direct insertion into the samples. Water-holding capacity (WHC) was analyzed in accordance with the method described by Hamm (1961).

Cooking loss (CL) was measured using the right Pectoralis major muscle, by the method described by Honikel (1987), whereby the samples were cooked in a water bath $\left(85^{\circ} \mathrm{C}\right)$ for $30 \mathrm{~min}$. This variable was determined as the difference between the initial and final weights. To evaluate tenderness were employed a method using the Warner-Bratzler dis-positive (Lyon et al. 1998), that was coupled to the TA-XT2i texture analyzer (Stable Micro Systems, Ltd, Godalming, UK), in the samples previously cooked for the analysis of cooking loss. Subsequently, three 3-cm-long subsamples with a section area of $1 \mathrm{~cm} 2$ were obtained from each cooked sample. These were positioned with the fibers perpendicular to the Warner-Bratzler dispositive (HDP/BSW Warner-Bratzler, $5 \mathrm{~mm} / \mathrm{s}$ crosshead speed). Results for shear force were expressed in Newton (N).

The chemical composition was studied by quantifying the moisture, protein, fat and mineral matter contents. The percentages of moisture, protein and mineral matter were determined in accordance with methods 950.46, 977.14 and 920.153, respectively (AOAC 2011). The fat (total lipids) percentage was determined by following the methodology pro-posed by Bligh and Dyer (1959). The cholesterol concentration was determined by an adapted version of the technique described by Saldanha et al. (2004), whereby $0.5 \mathrm{~g}$ of lyophilized sample were weighed in Falcon tubes to which $6 \mathrm{~mL}$ ethanol and $4 \mathrm{~mL}$ of a $50 \% \mathrm{KOH}$ solution were subsequently added. Tubes were kept under agitation in a water bath $\left(40^{\circ} \mathrm{C}\right)$ until the sample was fully dissolved. Next, the samples were kept in a water bath $\left(60^{\circ} \mathrm{C}\right)$ for another $10 \mathrm{~min}$ and $5 \mathrm{~mL}$ of distilled water were added. Thereafter, the samples were washed three times with $10 \mathrm{~mL}$ of $\mathrm{n}$-hexane to separate the phases. A 3-mL aliquot was removed from the upper phase and evaporated with $\mathrm{N} 2$. Subsequently, $0.5 \mathrm{~mL}$ of isopropanol was added and the tubes were agitated in a vortex. The enzymatic reagent for cholesterol analysis was then added $(3 \mathrm{~mL})$. Samples were kept in a water bath for $10 \mathrm{~min}\left(37{ }^{\circ} \mathrm{C}\right)$ and read in a spectrophotometer set at the wavelength indicated by the enzymatic reagent's manufacturer. 
Total, soluble and insoluble collagen concentrations were quantified by determining the amino acid hydroxyproline, following the methodologies proposed by Woessner Junior (1961) and Cross et al. (1973) and adapted by Hadlich et al. (2006) and by Carvalho et al. (2021). Five grams of frozen meat cut into small cubes were weighed in 50 mL Falcon tubes. Immediately after being heated in a water bath $\left(80^{\circ} \mathrm{C}\right.$ for $\left.2 \mathrm{~h}\right), 20 \mathrm{~mL}$ of distilled water were added to the samples. These were then homogennized in an Ultra-turrax (Marconi MA102, Marconi Equipamentos Para Laboratórios Ltd., Piracicaba, São Paulo, Brazil) (22,000 rpm for $1 \mathrm{~min}$ ) and centrifuged (Himac CR22N, Hitachi Koki do Brasil Ltd., Indaiatuba, São Paulo, Brasil) (4,000 rpm for $15 \mathrm{~min})$. The samples were transferred to autoclavable tubes, with the solid fraction separated from the liquid fraction. Thirty milliliters of $6 \mathrm{~N} \mathrm{HCl}$ were added to the liquid fraction and $50 \mathrm{~mL}$ of $6 \mathrm{~N} \mathrm{HCl}$ were added to the solid fraction (Woessner Junior 1961). All samples were hydrolyzed in an autoclave (Phoenix Luferco AV-75 Plus, Phoenix Industria e Comercio de Equipamentos Científicos Ltd., Araraquara, São Paulo, Brazil) for 4 h (120 ${ }^{\circ} \mathrm{C}$ and 1 atm) (Cross et al. 1973). After hydrolysis, the pH of all samples was adjusted to 6.0 with a pH meter (mPA-210, MS Tecnopon Equipamentos Especiais Ltd., Piracicaba, São Paulo, Brazil) using 2N NaOH. The solid fraction was filtered into a 250-mL volumetric flask and the balloon volume was filled with distilled water. Subsequently, a 10-mL aliquot was removed from each filtered sample and transferred to a new volumetric flask $(100 \mathrm{~mL}$ for the solid fraction and $50 \mathrm{~mL}$ for the liquid fraction). Afterwards, the balloon volume was again filled with distilled water (Hadlich et al. 2006). Next, 2-mL aliquots of the solid and liquid fractions were transferred to test tubes, to which $1 \mathrm{~mL}$ oxidation reagent (Chloramine-T $1.41 \%)$ and $1 \mathrm{~mL}$ color reagent (10 g p-dimethylaminobenzaldehyde in $35 \mathrm{~mL}$ perchloric acid $60 \%$ and $65 \mathrm{~mL}$ isopropanol) (Carvalho et al., 2021) were added. To finish, samples were taken to a water bath $\left(15 \mathrm{~min}, 60^{\circ} \mathrm{C}\right)$ and then read in a spectrophotometer (Shimadzu UV-1800, Shimadzu Corporation, Kyoto, Japan) under $\lambda=560 \mathrm{~nm}$. Results for the soluble collagen concentration were obtained with the liquid fraction of the sample, whereas insoluble collagen concentration results were obtained with the solid fraction. The standard curve was analyzed using a solution of known hydroxyproline concentration. Calculations for the collagen concentration were made using the formulae described by Hadlich et al. (2006) and represented below, adopting $\mathrm{F}=8.33$ (average of absorbance values equivalent to $1 \mathrm{mg}$ hydroxyproline obtained from the standard curve) and the hydroxyproline-to-collagen conversion factor of 7.14.

$\%$ Total collagen $=\%$ Insoluble collagen $+\%$ Soluble collagen

$\%$ Soluble collagen $=\underline{\text { absorbance } \times \mathrm{F} \times 100 \times 50 \times 7,14 \times 106 \times 100}$

$10 \times 2$ x sample weight $(\mathrm{g})$

$\%$ Insoluble collagen $=\underline{\text { absorbance } \times \mathrm{F} \times 250 \times 100 \times 7,14 \times 106 \times 100}$

$10 \times 2 \times$ sample weight $(\mathrm{g})$

Sarcomere length was evaluated as proposed by Cross et al. (1981). A 0.5-g raw meat sample was homogenized in an Ultra-turrax (Marconi MA102, Marconi Equipamentos Para Laboratórios Ltd., Piracicaba, São Paulo, Brazil) (15,000 rpm for $30 \mathrm{~s})$ with $15 \mathrm{~mL} \mathrm{KI}(0.08 \mathrm{~mol} / \mathrm{L})$ and $15 \mathrm{~mL} \mathrm{KCl}(0.08 \mathrm{~mol} / \mathrm{L})$. One drop of the homogenate was transferred to the slide, which was covered by a cover slip, and the set was quickly read by a phase contrast microscope under 1000x magnification (100x objective, 10x ocular lens). One drop of immersion oil was then poured onto the cover slip to measure sarcomere length. Twelve counts with at least six viable sarcomeres were performed per slide.

The experiment was set up as a completely randomized design with two myopathy severity degrees and a control group (normal samples), in 60 replicates. Data were analyzed by the "One-Way ANOVA" procedure of SAS software (Statistical Analysis System, 2012). All data were subjected to analysis of variance and, in case of significance $(\mathrm{P}<0.05)$, the means were 
compared by Tukey's test.

\section{Results}

The breast meat from the birds affected by the myopathy showed higher lightness $\left(\mathrm{L}^{*}\right)(\mathrm{P}=0.0086)$ and yellowness $\left(\mathrm{b}^{*}\right)$ $(\mathrm{P}<0.0001)$ values on the outer surface than the meat from the birds which were not affected with the abnormality (Table 1). Redness also increased $(\mathrm{P}<0.0001)$ with the severity degree (from 0.3 in the meat from normal chickens to 2.2 in the birds showing a severe degree of white striping). By contrast, no variations were detected $(\mathrm{P}>0.05)$ for the $\mathrm{a}^{*}$ values in the inner surface of the breast muscle from broilers affected by white striping myopathy. Likewise, higher $\mathrm{L}^{*}(\mathrm{P}=0.0047)$ and $\mathrm{b}^{*}$ $(\mathrm{P}=0.0002)$ were observed in those animals compared to the birds considered normal.

Table 1. Mean values of lightness $\left(\mathrm{L}^{*}\right)$, redness $\left(\mathrm{a}^{*}\right)$ and yellowness $\left(\mathrm{b}^{*}\right)$ of outer and inner surfaces of Pectoralis major muscle from broiler chickens affected by different severity degrees of white striping myopathy.

\begin{tabular}{ccccccccc}
\hline \multirow{2}{*}{$\begin{array}{c}\text { Severity } \\
\text { degree }\end{array}$} & \multicolumn{3}{c}{ Color of outer surface } & & \multicolumn{3}{c}{ Color of inner surface } \\
& $\mathrm{L}^{*}$ & $\mathrm{a}^{*}$ & $\mathrm{~b}^{*}$ & & $\mathrm{~L}^{*}$ & $\mathrm{a}^{*}$ & $\mathrm{~b}^{*}$ \\
\cline { 2 - 4 } \cline { 5 - 8 } Normal & $59.2 \pm 2.2^{\mathrm{b}}$ & $0.3 \pm 0.7^{\mathrm{c}}$ & $0.8 \pm 0.7^{\mathrm{b}}$ & & $57.0 \pm 3.4^{\mathrm{b}}$ & $0.3 \pm 0.5$ & $3.2 \pm 1.8^{\mathrm{b}}$ \\
Moderate & $61.2 \pm 1.9^{\mathrm{a}}$ & $1.4 \pm 0.8^{\mathrm{b}}$ & $3.2 \pm 1.8^{\mathrm{a}}$ & & $58.6 \pm 4.5^{\mathrm{ab}}$ & $0.3 \pm 0.7$ & $4.8 \pm 2.2^{\mathrm{a}}$ \\
Severe & $60.9 \pm 2.4^{\mathrm{a}}$ & $2.2 \pm 1.1^{\mathrm{a}}$ & $2.4 \pm 1.3^{\mathrm{a}}$ & & $60.1 \pm 2.8^{\mathrm{a}}$ & $0.3 \pm 0.6$ & $5.0 \pm 2.3^{\mathrm{a}}$ \\
$P$ value & 0.0086 & $<0.0001$ & $<0.0001$ & & 0.0047 & 0.4009 & 0.0002 \\
\hline
\end{tabular}

${ }^{\mathrm{a}-\mathrm{b}}$ Means followed by different letters in the same column, only within a variable, are significantly different by the Tukey's test $(P<0.05)$. Source: Authors.

White striping did not influence ( $\mathrm{P}>0.05)$ the $\mathrm{pH}$ or WHC of breast meat from broilers, averaging 5.96 and $71.64 \%$, respectively (Table 2). Cooking loss decreased $(\mathrm{P}<0.0001)$ as the severity degree of the myopathy increased (from $30.94 \%$ in the meat from unaffected birds to $21.65 \%$ in the meat from those showing a severe degree of the disorder). When shear force was evaluated increased toughness $(\mathrm{P}=0.0076)$ was observed in the samples affected with the condition at moderate and severe degrees.

Table 2. Mean values $\mathrm{pH}$, water-holding capacity (WHC), cooking loss (CL) and shear force (SF) of Pectoralis major muscle from broiler chickens affected by different severity degrees of white striping myopathy.

\begin{tabular}{lcccc}
\hline & \multicolumn{3}{c}{ Severity degree } & P value \\
& Normal & Moderate & Severe & 0.7629 \\
\cline { 2 - 4 } $\mathrm{pH}$ & $5.97 \pm 0.09$ & $5.95 \pm 0.15$ & $5.97 \pm 0.09$ & 0.5486 \\
$\mathrm{WHC}(\%)$ & $72.19 \pm 3.83$ & $71.12 \pm 3.36$ & $71.61 \pm 3.47$ & $<0.0001$ \\
$\mathrm{CL}(\%)$ & $30.94 \pm 2.30^{\mathrm{a}}$ & $26.69 \pm 2.29^{\mathrm{b}}$ & $21.65 \pm 2.65^{\mathrm{c}}$ & 0.0076 \\
$\mathrm{SF}(\mathrm{N})$ & $20.44 \pm 6.88^{\mathrm{b}}$ & $26.03 \pm 7.37^{\mathrm{a}}$ & $25.21 \pm 6.25^{\mathrm{a}}$ & \\
\hline
\end{tabular}

${ }^{a-c}$ Means followed by different letters in the same row, only within a variable, are significantly different by the Tukey's test ( $P$ $<0.05)$. Source: Authors.

No effect $(\mathrm{P}>0.05)$ of the myopathy was observed on the percentages of moisture and mineral matter in the breast meat (Table 3). The lipid concentration rose $(\mathrm{P}<0.001)$ from $1.60 \%$ in the meat from normal birds to $2.57 \%$, on average, in the meat from the birds affected with the abnormality. Like the lipid concentration, cholesterol levels were also influenced by the 
myopathy ( $\mathrm{P}=0.0133)$, increasing from $84.60 \mathrm{mg} / 100 \mathrm{~g}$ in the control group to $91.73 \mathrm{mg} / 100 \mathrm{~g}$ in the meat from the birds which exhibited a severe degree of white striping.

Table 3. Chemical composition and cholesterol concentration of Pectoralis major muscle from broiler chickens affected by different severity degrees of white striping myopathy.

\begin{tabular}{lcccc}
\hline & & Severity degree & & \\
& Normal & Moderate & Severe & $P$ value \\
Protein (\%) & $22.66 \pm 1.37^{\mathrm{a}}$ & $23.38 \pm 1.59^{\mathrm{a}}$ & $21.47 \pm 1.39^{\mathrm{b}}$ & 0.0001 \\
Total lipids (\%) & $1.60 \pm 0.43^{\mathrm{b}}$ & $2.72 \pm 0.85^{\mathrm{a}}$ & $2.42 \pm 0.65^{\mathrm{a}}$ & $<0.0001$ \\
Moisture (\%) & $73.81 \pm 1.39$ & $73.27 \pm 1.86$ & $73.98 \pm 1.75$ & 0.2832 \\
Mineral matter (\%) & $1.53 \pm 0.22$ & $1.47 \pm 0.25$ & $1.42 \pm 0.24$ & 0.3729 \\
Cholesterol (mg/100g) & $84.60 \pm 3.81^{\mathrm{b}}$ & $85.61 \pm 5.47^{\mathrm{ab}}$ & $91.73 \pm 6.18^{\mathrm{a}}$ & 0.0133 \\
\hline
\end{tabular}

a-b Means followed by different letters in the same row, only within a variable, are significantly different by the Tukey's test $(P<0.05)$. Source: Authors.

Total, soluble and insoluble collagen concentrations rose $(\mathrm{P}<0.05)$ with the severity of the myopathy (Table 4$)$. Sarcomere length measured in samples of the Pectoralis major muscle of broiler chickens was not influenced by the white striping myopathy.

Table 4. Collagen concentration and sarcomere length of Pectoralis major muscle from broiler chickens affected by different severity degrees of white striping myopathy.

\begin{tabular}{lcccc}
\hline & & Severity degree & & \\
& Normal & Moderate & Severe & $P$ value \\
Total collagen $(\%)$ & $0.22 \pm 0.09^{\mathrm{b}}$ & $0.28 \pm 0.06^{\mathrm{ab}}$ & $0.35 \pm 0.07^{\mathrm{a}}$ & $<0.0001^{\mathrm{a}}$ \\
Soluble collagen $(\%)$ & $0.10 \pm 0.05^{\mathrm{b}}$ & $0.12 \pm 0.03^{\mathrm{ab}}$ & $0.14 \pm 0.05^{\mathrm{a}}$ & 0.0196 \\
Insoluble collagen $(\%)$ & $0.12 \pm 0.06^{\mathrm{b}}$ & $0.16 \pm 0.05^{\mathrm{ab}}$ & $0.21 \pm 0.07^{\mathrm{a}}$ & 0.0006 \\
Sarcomere $(\mu \mathrm{m})$ & $1.67 \pm 0.03$ & $1.65 \pm 0.07$ & $1.69 \pm 0.06$ & 0.2816 \\
\hline
\end{tabular}

${ }^{\mathrm{a}-\mathrm{b}}$ Means followed by different letters in the same row, only within a variable, are significantly different by the Tukey's test $(\mathrm{P}<0.05)$. Source: Authors.

\section{Discussion}

In samples affected with myopathies, changes in lightness may be attributed to alterations in fiber membrane integrity that contribute to increasing fluid losses, which consequently makes the meat surface brighter (Soglia et al. 2016; Aguirre et al. 2018). Recent studies (Baldi et al. 2018; Baldi et al. 2019) have reported changes in breast meat color in broilers affected with myopathies according to the sampled region (surface layers or deep layers), with the deep layers being light-er than the surface layers. The higher results obtained in this study (for lightness and yellowness, in both filet surfaces) may be explained by changes in muscle tissue caused by the degeneration of the affected muscle (severe fibrotic response) (Zotte et al. 2017) and by the increased amount of fat, respectively (Petracci et al. 2013; Mudalal et al. 2015; Sánchez-Brambila et al. 2016; Kuttappan et al. 2017; Baldi et al. 2019). The increased redness, in turn, is possibly related to the amount of myoglobin (Zotte et al. 2017), heme pigments (Petracci et al. 2017) or hemorrhages on the surface (Zhuang and Bowker 2018) of the affected samples.

Although no $\mathrm{pH}$ change was observed between the normal samples and those affected with different degrees of the white striping myopathy, most of the recently published research on muscle anomalies in chicken breast describes a $\mathrm{pH}$ increase (Kuttappan et al. 2017; Zotte et al. 2017; Aguirre et al. 2018; Baldi et al. 2018; Baldi et al. 2019; Gratta et al. 2019). Due to genetic selection for greater weight gain in less time, heavier birds and birds with a higher breast yield seem to be more prone to 
developing muscle abnormalities (Baldi et al. 2018). Some studies have already reported the relationship between bird growth rate and myopathies (Kuttappan et al. 2012a; Kutappan et al. 2013; Trocino et al. 2015; Kuttappan et al. 2017), suggesting an increase in their incidence with increasing filet weight (Kuttappan et al. 2017) and also an association between severity and bird age and with filet weight and thickness (Gratta et al. 2019). The reduced muscle vascularization and glycogen reserves observed in heavy chickens may compromise the supply of energy to the muscle fibers (Alnahhas et al. 2016; Baldi et al. 2018). The higher $\mathrm{pH}$ values could then be explained by the correlation between glycogen storage and breast muscle weight (Le BihanDuval et al. 2008; Zotte et al. 2017), since larger filets may present reduced glycolytic potential, which would result in a higher pH (Aguirre et al. 2018; Baldi et al. 2019).

Previous research (Trocino et al. 2015; Mudalal et al. 2015; Tasoniero et al. 2016; Zambonelli et al. 2016; Soglia et al. 2016; Aguirre et al. 2018) with agreeing results for cooking loss indicates that more fluid is lost in samples affected with myopathies when compared to meat classified as normal. This is especially true if more than one myopathy is observed in the sample (Gratta et al. 2019). However, in the present study, cooking loss was found to decrease with the degree of severity. The increased cooking loss reported by the abovementioned researchers was thought to be related to a reduction of myofibrillar proteins, fiber shortening and increased connective tissue or collagen contents, which might reduce wa-ter-holding capacity and, consequently, increase cooking loss. Despite the observed reduction in cooking loss and the lack of effects of the myopathy on water-holding capacity in the current experiment, shear force values increased, which is likely due to the muscle hypertrophy characteristic of this myopathy.

As also reported by Baldi et al. (2018), we observed a reduction $(\mathrm{P}=0.0001)$ in protein concentration and an increase $(\mathrm{P}<0.0001)$ in fat content in the studied samples. The negative effect of myopathies on the chemical composition of meat is likely due to the important alterations they induce in the muscle structure (Soglia et al. 2016; Soglia et al. 2016b; Tasoniero et al. 2016; Baldi et al. 2018; Baldi et al. 2019), directly affecting its protein content (Sihvo et al. 2014; Tasoniero et al. 2016), whereas myodegeneration and adipose tissue (lipidosis) and connective tissue (fibrosis) deposition in areas of necrotic muscle fibers (Russo et al. 2015) explain the higher results for fat percentage in this type of sample (Kuttappan et al. 2013; Sihvo et al. 2014; Baldi et al. 2018; Baldi et al. 2019; Soglia et al. 2016b; Radaelli et al. 2017; Gratta et al. 2019; Marchesi et al. 2019). In samples affected with myopathies, increases are expected in the percentage of moisture, which originates from edemas resulting from inflammatory processes (Sihvo et al. 2014; Soglia et al. 2016). However, in the present study, white striping did not influence moisture percentage in chicken breast.

Changes in the concentration, structure and composition of the collagen present in samples affected with the myopathy may compromise their quality, as they play a key role in meat tenderness (Maiorano et al. 2015; Baldi et al. 2019). In the present study, the increasing collagen concentrations (Table 4) resulted in decreased tenderness in the meat of the birds with moderate and severe degrees of the myopathy (Table 2), whose shear force results were higher than those obtained in the normal samples. This reduced tenderness in the affected muscle is linked not only to the higher concentrations of collagen, but also to its structural characteristics (Velleman et al. 2017). In our study, sarcomere length was not influenced by the myopathy. Increased collagen concentrations in samples from animals affected with pectoral myopathies possibly prevented sarcomere shortening (Tijare et al. 2016; Sun et al. 2018).

\section{Conclusion}

Although there are statistical differences for some evaluated parameters and, even so, these results are considered numerically normal based on previously published literature, we emphasize that the white striping abnormality alters chicken breast meat quality, especially regarding to the protein and fat concentrations, which can offer consumers products with 
nutritional quality different from the average specified on the packaging. We suggest that more detailed studies about the biochemical effects of White Striping myopathy should be carried out.

\section{Acknowledgments}

The authors thank the São Paulo Research Foundation (Fundação de Amparo à Pesquisa do Estado de São Paulo FAPESP, 2015/08471-8, 2015/14584-0 and 2019/11621-2) for financial support.

\section{References}

ABPA - Brazilian Association of Animal Protein. 2020. "Annual report 2020.” <http://abpa-br.org/mercados/\#relatorios>.

Aguirre, M. E., Owens, C. M., Miller, R. K., \& Alvarado, C. Z. (2018). Descriptive sensory and instrumental texture profile analysis of woody breast in marinated chicken. Poultry Science, 97, 1456-1461.

Alnahhas, N., Berri, C., Chabault, M., Chartrin, P., Boulay, M., Bourin, M.C. \& LE Bihan-Duval, E. (2016). Genetic parameters of white striping in relation to body weight, carcass composition, and meat quality traits in two broiler lines divergently selected for the ultimate pH of the pectoralis major muscle. $B M C$ Genetics, 17, 61-70.

AOAC, 2011. Official Methods of Analysis of AOAC International (18th ed.) (Washington, DC: Association of Analytical Chemists).

Baldi, G., Soglia, F., Mazzoni, M., Sirri, F., Canonico, L., Babini, E., Laghi, L., Cavani, C. \& Petracci, M. (2018). Implications of white striping and spaghetti meat abnormalities on meat quality and histological features in broilers. Animal, 12, 164-173.

Baldi, G., Soglia, F., Laghi, L., Tappi, S., Rocculi, P., Tavaniello, S., Prioriello, D., Mucci, R., Maiorano, G. \& Petracci, M. (2019). Comparison of quality traits among breast meat affected by current muscle abnormalities. Food Research International, 115, 369-376.

Bligh, E. G. \& Dyer, W. J. (1959). A rapid method for total lipid extraction and purification. Canadian Journal of Biochemistry and Physiology, 37,911 - 917.

Carvalho, L. T., Owens, C. M., Giampietro-Ganeco, A., Mello, J. L. M., Ferrari, F. B., Carvalho, F. A. L., Souza, R. A., Amoroso, L., Souza, P. A., Borba, H. \& Trindade, M.A. Quality of turkeys breast meat affected by White Striping myopathy. <https://www.sciencedirect.com/ science/article/pii/S0032579121000560>

Cross, H. R., Carpenter, Z. L. \& Smith, G. C. (1973). Effects of intramuscular collagen and elastin on bovine muscle tenderness. Journal of Food Science, 38, 998-1003.

Cross, H. R., West, R. L. \& Dutson, T. R. (1981). Comparison of methods for measuring sarcomere length in beef semitendinosus muscle. Meat Science, 5, 261266.

Dalle Zotte, A, Tasoniero, G., Puolanne, E., Remignon, H., Cecchinato, M., Catelli, E. \& Cullere, M. (2017). Effect of “wooden breast” appearance on poultry meat quality, histological traits, and lesions characterization. Czech Journal of Animal Science, 62, 51-57.

Gratta, F., Fasolato, L., Birolo, M., Zomeño, C., Novelli, E., Petracci, M., Pascual, A., Xiccato, G. \& Trocino, A. (2019). Effect of breast myopathies on quality and microbial shelf life of broiler meat. Poultry Science, 98, 2641-2651.

Hadlich, J. C., Morales, D. C., Silveira, A. C., Oliveira, H. N. \& Chardulo, L. A. L. (2006). Efeito do colágeno na maciez da carne de bovinos de distintos grupos genéticos. Acta Scientiarum. Animal Sciences, 28, 57-62.

Hamm, R. (1961). Biochemistry of meat hydration. Advances in Food Research, 10, 355-463.

Honikel, K. O. (1987). The water binding of meat. Fleischwirttsch, 67, 1098-1102.

Kuttappan, V. A., Brewer, V. B., Apple, J. K., Waldroup, P. W. \& Owens, C. M. (2012). Influence of growth rate on the occurrence of white striping in broiler breast fillets. Poultry Science, 91(10), 2677-2685.

Kuttappan, V. A., Lee, Y., Erf, G., Meullenet, J. F., Mckee, S. \& Owens, C.M. (2012b). Consumer acceptance of visual appearance of broiler breast meat with varying degrees of white striping. Poultry Science, 91, 1240-1247.

Kuttappan, V. A., Shivaprasad, H. L., Shaw, D. P., Valentine, B. A., Hargis, B. M., Clark, F. F., Mckee, S. R. \& Owens, C. M. (2013). Pathological changes associated with white striping in broiler breast muscles. Poultry Science, 92, 331-338.

Kuttappan, V. A., Owens, C. M., Coon, C., Hargis, B. M. \& Vazquez-Añon, M. (2017). Incidence of broiler breast myopathies at 2 different ages and its impact on selected raw meat quality parameters. Poultry Science, 96, 3005-3009.

Le Bihan-Duval, E., Debut, M., Berri, C.M., Sellier, N., Sante-Lhoutellier, V., Jego, Y. \& Beaumont, C. (2008). Chicken meat quality: genetic variability and relationship with growth and muscle characteristics. BMC Genetics, 9, 53.

Lee, Y. S., Owens, C. M. \& Meullenet, J. F. (2008). The Meullenet-Owens razor shear (MORS) for predicting poultry meat tenderness: its applications and optimization. Journal of Texture Studies, 39, 655-672. 
Lyon, C. E., Lyon, B. G. \& Dickens, J. A. (1998). Effects of carcass stimulation, deboning time, and marination on color and texture of broiler breast meat. Journal of Applied Poultry Research, 7, 53-60.

Maiorano, G., Wilkanowska, A., Tavaniello, S., Di Memmo, D., De Marzo, D. \& Gambacorta, M. (2015). Effect of intramuscular injections of DL- $\alpha$-tocopheryl acetate on growth performance and extracellular matrix of growing lambs. Animal, 9, 2060-2064.

Marchesi, J. A. P., Ibelli, A. M. G., Peixoto, J. O., Cantão, M. E., Pandolfi, J. R. C., Marciano, C. M. M., Zanella, R., Settles, M. L., Coutinho, L. L. \& Ledur, M. C. (2019). Whole transcriptome analysis of the pectoralis major muscle reveals molecular mechanisms involved with white striping in broiler chickens. Poultry Science, 98, 590-601.

Meullenet, J. F., Jonville, E., Grezes, D. \& Owens, C. M. (2004). Prediction of the texture of cooked poultry pectoralis major muscles by near-infrared reflectance analysis of raw meat. Journal of Texture Studies, 35, 573-585.

Mudalal, S., Lorenzi, M., Soglia, F., Cavani, C. \& Petracci, M. (2015). Implications of white striping and wooden breast abnormalities on quality traits of raw and marinated chicken meat. Animal, 9(4), 728-734.

Petracci, M., Mudalal, S., Bonfiglio, A. \& Cavani, C. (2013). Occurrence of white striping and its impact on breast meat quality in broiler chickens. Poultry Science, $92,1670-1675$

Petracci, M., Soglia, F. \& Berri, C. (2017). Muscle metabolism and meat quality abnormalities. In: Petracci, M. \& Berri, C. (Eds), Poultry quality evaluation, Ed. Duxford: Cambridge, p. 51-75.

Radaelli, G., Piccirillo, A., Birolo, M., Bertotto, D., Gratta, F., Ballarin, C., Vascellari, M., Xiccato, G. \& Trocino, A. (2017). Effect of age on the occurrence of muscle fiber degeneration associated with myopathies in broiler chickens submitted to feed restriction. Poultry Science, 96, 309-319.

Russo, E., Drigo, M., Longoni, C., Pezzotti, R., Fasoli, P. \& Recordati, C. (2015). Evaluation of White Striping prevalence and predisposing factors in broilers at slaughter. Poultry Science, 94, 1843-1848.

Saldanha, T., Mazalli, M. R. \& Bragagnolo, N. (2004). Avaliação comparativa entre dois métodos para determinação do colesterol em carnes e leite. Ciência e Tecnologia de Alimentos, 24, 109-113.

Sánchez-Brambila, G., Bowker, B. C. \& Zhuang, H. (2016). Comparison of sensory Texture attributes of broiler breast fillets with different degrees of white striping. Poultry Science, 95, 2472-2476.

SAS. (2012). Statistical Analysis System user's guide. SAS Institute. Version 9.2, Cary.

Sihvo, H. K., Immonen, K. \& Puolanne, E. (2014). Myodegeneration with fibrosis and regeneration in the pectoralis major muscle of broilers. Veterinary Pathology, 51, 619-623.

Soglia, F., Mudalal, S., Barbini, E., Di Nunzio, M., Mazzoni, M., Sirri, F., Cavani, C. \& Petracci, M. (2016). Histology, composition, and quality traits of chicken Pectoralis major muscle affected by wooden breast abnormality. Poultry Science, 95, 651-659.

Soglia, F., Laghi, L., Canonico, L.C., Cavani, C. \& Petracci, M. (2016). Functional property issues in broiler breast meat related to emerging muscle abnormalities. Food Research International, 89(3), 1071-1076.

Sun, X., Koltes, D. A., Coon, C. N., Chen, K. \& Owens, C. M. (2018). Instrumental compression force and meat attribute changes in woody broiler breast fillets during short-term storage. Poultry Science, 0, 1-7. 10.3382/ps/pey107.

Tasoniero, G., Cullere, M., Cecchinato, M., Puolanne, E. \& Dalle Zotte, A. (2016). Technological quality, mineral profile and sensory attributes of broiler chicken breasts affected by white striping and wooden breast myopathies. Poultry Science, 95, 2707-2714.

Tijare, V. V., Yang F. L., Kuttappan V. A., Alvarado, C. Z., Coon, C. N. \& Owens, C. M. (2016). Meat quality of broiler breast fillets with white striping and woody breast muscle myopathies. Poultry Science, 95, 2167-2173.

Trocino, A., Piccirillo, A., Birolo, M., Radaelli, G., Bertotto, D., Filiou, E., Petracci, M. \& Xiccato, G. (2015). Effect of genotype, gender and feed restriction on growth, meat quality and the occurrence of white striping and wooden breast in broiler chickens. Poultry Science, 94, $2996-3004$.

Velleman, S. G., Clark, D. L. \& Tonniges, J. R. (2017). Fibrillar collagen organization associated with broiler wooden breast fibrotic myopathy. Avian Diseases. $61,481-490$.

Woessner Junior, J. F. (1961). The determination of hydroxyproline in tissue and protein samples containing small proportions of this amino acid. Archives of Biochemistry and Biophysics, 93, 440-447.

Zambonelli, P., Zappaterra, M., Soglia, F., Petracci, M., Sirri, F., Cavani, C. \& Davoli, R. (2016). Detection of differentially expressed genes in broiler pectoralis major muscle affected by white striping - wooden breast myopathies. Poultry Science, 95, 2771-2785.

Zhuang, H. \& Bowker, B. (2018). The wooden breast condition results in surface discoloration of cooked broiler pectoralis major. Poultry Science, 97, 44584461 